\title{
Establishing the Identity from the Skeletal Remains of Alum Bheg, a Martyr from the 1857 Indian Freedom Struggle
}

\author{
Ashutosh Kumar $^{1}$ Sanjib Kumar Ghosh ${ }^{1}$ (i) Vikas Pareek ${ }^{2}$ \\ ${ }^{1}$ Department of Anatomy, All India Institute of Medical Sciences, \\ Patna, Bihar, India \\ 2 Division of Computational Neuroscience and Neuroimaging, \\ National Brain Research Centre, Manesar, India \\ Address for correspondence Sanjib Kumar Ghosh, MD, Department \\ of Anatomy, All India Institute of Medical Sciences, Phulwarisharif, \\ Patna-801507, Bihar, India (e-mail: drsanjibghosh@aiimspatna.org).
}

J Morphol Sci 2019;36:321-328.

Abstract

Keywords
- alum bheg
- anthropometry
- identification
- 1857 indian freedom
struggle
- skull

Introduction The present study was undertaken to analyze the morphological features of a skull supposed to be that of Alum Bheg, a martyr from the 1857 Indian Freedom Struggle (also called the Sepoy Mutiny), using established methods to validate identity with regards to age and height as available in the note found with the skull ( $\sim 32$ years old and 5 feet $7 \frac{1}{2}$ inch tall).

Materials and Methods Identification of the gender of the skull was performed based on established criteria. Analysis for closure of skull sutures (cranial and facial) and measurement of orbitomedial (OM) and maxillomedial (MM) facial anthropometric lines were undertaken to provide an estimated age against each examined suture, as well as against a group of sutures through established scoring systems. Furthermore, the approximate height of the individual was estimated from the skull length using regression equations from a reference adult Indian male population. All of the measurements were made on the digital images of the skull using a digital image analyzer (Image J software, National Institutes of Health, Bethesda, MD, USA).

Results Established criteria confirmed that the skull was of a male individual, and the skull sutures and age related morphological changes in the bones indicate that it belonged to an individual in an age range between 20 and 50 years old, with an average of 30 years old, and an approximate height between 5 feet 8.2 inches to 6 feet 1.3 inches.

Conclusion The observed values are in approximation with those mentioned in historical notes, and slight differences may be attributed to gross reporting of the original values or limitations of anthropometric analysis. Further biological tests will be required to validate the identity beyond reasonable doubt. received

February 16, 2019

accepted

August 14, 2019

published online

August 14, 2019
DOI https://doi.org/

10.1055/s-0039-1698376.

ISSN 2177-0298.

\footnotetext{
(C) 2019. The Author(s).

This is an open access article published by Thieme under the terms of the Creative Commons Attribution-NonDerivative-NonCommercial-License, permitting copying and reproduction so long as the original work is given appropriate credit. Contents may not be used for commercial purposes, or adapted, remixed, transformed or built upon. (https://creativecommons.org/ licenses/by-nc-nd/4.0/)

Thieme Revinter Publicações Ltda., Rua do Matoso 170, Rio de Janeiro, RJ, CEP 20270-135, Brazil
} 


\section{Introduction}

The 1857 Indian Freedom Struggle (also called the Sepoy Mutiny) was a widespread, albeit unsuccessful, rebellion against the rule of the British East India Company between 1857 and 1858 . The event began on May $10^{\text {th }} 1857$ in Meerut, and later spread to Delhi, Agra, Kanpur, Lucknow, and other parts of India, which was undivided at that time. The rebellion posed a considerable threat to the British authority in South Asia and, therefore, was aggressively subdued, eventually culminating with the defeat of the rebels in Gwalior on June $20^{\text {th }} 1858 .^{1}$

During the course of the mutiny, violent skirmishes were reported from different parts of India, which at times speak volumes about the exceptional cruelty inflicted on both sides, that is, on British officers and civilians (including women and children) by the rebels and on the rebels and their supporters (sometimes entire villages) by the British. One of these intriguing incidents has recently been reported by historian Kim A. Wagner, a senior lecturer in British Imperial History at the Queen Mary University of London, in his recent book "The skull of Alum Bheg-The life and death of a rebel of 1857."1 In this text, Wagner has narrated the incidents related to Alum Bheg (or Alim Beg), who was a Havildar in the $46^{\text {th }}$ Regiment of the Bengal Native Infantry and probably belonged to what was then the United Province (modern day Uttar Pradesh). As reported by Wagner, on July $9^{\text {th }} 1857$, Alum Bheg and his fellow sepoys declared a revolt against the imperial rule, which led to the killing of many from the British side. The incident took place somewhere near Sialkot (in modern day Pakistan), which was a part of the North Indian heartland in those days. Alum Bheg was eventually arrested from Madhopur (a town in the Indian part of Punjab) and was tried for war crimes in Sialkot. He was charged with murder and was blown up from the mouth of a canon. The tragic story of Alum Bheg surfaced more than a century later, as a courtesy from Irish captain Authur Robert George Costello. ${ }^{1}$

Costello was a captain in the $7^{\text {th }}$ Dragoon Guards, which was dispatched to India after the revolt had erupted and shook the core of the British Colonial Empire. Costello was present at the execution of Alum Bheg and supposedly collected his skull as a war trophy (a prevalent practice in those times) and returned to London with it. In accordance with the fate of historical relics, the skull of Alum Bheg changed hands and was discovered in 1963 in a store room of the Lord Clyde pub (named after Collin Thomson, also known as Lord Clyde, a military commander who was instrumental in crushing the mutiny in north and northwestern India) of London. The links with the history of the Indian Mutiny is a testimony to the possibility that Costello or some other British soldier could have visited this Victorian-era pub and deposited the skull there. The historical facts about the skull were revealed from a handwritten note which was neatly folded and left in an orbit of the skull itself ( - Fig. 1). Along with a brief description of his job as a soldier and the reasons of the execution, the approximate age and height of Alum Bheg at the time of his execution were found mentioned in the note, as 32 years old and 5 feet and $71 / 2$ inches, respectively. ${ }^{1}$

The skull is now in custody of the historian Kim Wagner, who provided us the digital images and documented details

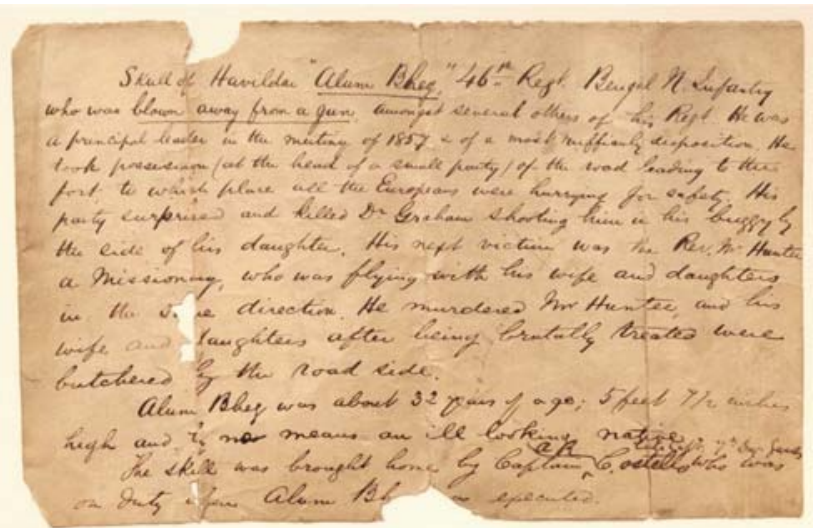

Fig. 1 Photograph of the handwritten note which was neatly folded and left in an orbit of the skull itself and revealed the historical facts about the skull.

necessary for the present study. We hypothesized, based on the available historical documents, that this 160 year old human skull should be treated as a solemn object from a disturbing part of British history in the Indian subcontinent. Furthermore, the skull may be repatriated to the family members of the 'martyr', or deposited at a repository for British Imperial History to avail optimum public recognition, to ensure a humane culmination of this dark episode from the past. To achieve this, it is necessary to establish the identity of the skull beyond reasonable doubt and, hence, we performed the present study to analyze the age-related changes in the morphological features of this skull and performed anthropometric measurements using established methods in an attempt to validate the identity of the skull from its details available in the documented literature.

\section{Materials and Methods}

The present study was conducted in the Department of Anatomy of the All India Institute of Medical Sciences, Patna, India. The study materials constituted the high-resolution digital images (horizontal and vertical resolutions: $300 \mathrm{dpi}$ ) of the skeletal remains (a human skull with the left upper molar teeth, but with the lower jaw missing), and details of the historical note found with the skull were received via e-mail communication from the Department of British Imperial History at the Queen Mary University of London, which claimed that the skull was that of Alum Bheg, and related authentic literature available on the Internet. The images from the anterior, superior, lateral, posterior, and inferior aspect of the skull were considered for the assessment.

Identification of the gender of the skull was done based on the established criteria ( - Table 1 ). ${ }^{2}$ A meticulous analysis of the closure of the skull sutures (cranial and facial) was performed, from the external surface visible in all the selected views after appropriate zooming of the images (-Fig. 2). Furthermore, the measurement of the orbitomedial (OM) and maxillomedial (MM) facial anthropometric lines on the anterior view image were performed ( - Fig.3). All of the image analyses were performed using a digital image analyzer (Image 
Table 1 Gender determination in human skulls

\begin{tabular}{|c|c|c|c|}
\hline $\begin{array}{l}\text { Serial } \\
\text { Number }\end{array}$ & Skull trait & Male & Female \\
\hline 1. & General size & $\begin{array}{l}\text { Large (intracranial volume } \\
200 \text { cc or more) }\end{array}$ & Smaller and lighter with thinner walls \\
\hline 2. & Architecture & Rugged & Smooth \\
\hline 3. & Glabela & Prominent & Less pronounced \\
\hline 4. & Orbits & $\begin{array}{l}\text { Square, low placed, relatively } \\
\text { small with rounded margins }\end{array}$ & $\begin{array}{l}\text { Round, higher placed, relatively large } \\
\text { with sharp margins }\end{array}$ \\
\hline 5. & Supraorbital ridges & Prominent & Less prominent \\
\hline 6. & Forehead & Sloping, less rounded & Vertical, full \& infantile \\
\hline 7. & Frontonasal junction & Distinct angulation & Smoothly curved \\
\hline 8. & Cheek bones & Heavy, laterally arched & Lighter, compressed \\
\hline 9. & Zygomatic arch & Prominent & Less pronounced \\
\hline 10. & Frontal eminence & Small & Large \\
\hline 11. & Parietal eminence & Small & Large \\
\hline 12. & $\begin{array}{l}\text { Occipital area: muscle lines and } \\
\text { external occipital protuberance }\end{array}$ & Well-defined & Not marked \\
\hline 13. & Mastoid process & Medium to large, round \& blunt & Small to medium, smooth \& pointed \\
\hline 14. & Base: sites of muscle attachment & Well-marked & Less marked \\
\hline 15. & Digastric groove & Deep & Less deep \\
\hline 16. & Condylar facet & Long and slender & Shorter and broader \\
\hline 17. & Occipital condyles & Large & Small \\
\hline 18. & Palate & Large, broad \& tends to be $U$ shaped & Small, tends to be parabola shaped \\
\hline 19. & Frontal sinuses & Well-developed & Less developed \\
\hline 20. & Nasal aperture & High and narrow & Lower and broader \\
\hline 21. & Foramina & Large & Smaller \\
\hline 22. & Foramen magnum & Relatively large and long & Relatively small and round \\
\hline 23. & $\begin{array}{l}\text { External auditory meatus: bony } \\
\text { ridge along upper border }\end{array}$ & Prominent & Often absent \\
\hline 24. & Teeth & Large & Smaller \\
\hline
\end{tabular}

(Reference: Reddy KSN. Identification (Chapter 4). In: The Essentials of Forensic Medicine and Toxicology. $28^{\text {th }}$ edition. Reddy KSN (editor). Hyderabad: KS Devi, Medical Book Co.; 2009. p. 52-90.)

J software, National Institutes of Health, Bethesda, MD, USA). The Buikstra et $\mathrm{al}^{3}$ scoring system and the Meindl et al scoring system were used to provide an estimated age against each examined suture and group of sutures (-Table $\mathbf{2}$ ), 3,4 and the $\mathrm{MM} / \mathrm{OM}$ length index was matched for the approximate age range of the skull ( - Table 3). Moreover, the anterior skull view was screened for the presence of any age-related changes in the facial bones, as well as in the teeth (-Table $\mathbf{3}$ ), and the permanent molar teeth, the spheno-occipital synchondrosis, and the jugular growth plate (bilaterally) were evaluated against the standard age range mentioned in the literature (-Table 3).

Further, from the length of the skull, the approximate stature of the individual (to which it could have belonged) was calculated using regression equations (estimated height: $122.32+2.63 \times$ head length) for the stature of males derived from a reference study in the adult Indian male population, although the study represented only the central Indian geo- graphical region. ${ }^{5}$ As given in the reference study, ${ }^{5}$ the length of the skull was considered extending from the glabela to a point on the maximum convexity of the occiput (opisthocranion) in lateral view of the skull (-Fig. 4). The gender, age and stature of the individual bearing this skull were matched with that mentioned in the note found with the skull (-Fig. 1).

\section{Results}

Using the established criteria, the skull under study appears to belong to the male gender. Analysis of the closure of the studied single and group of sutures in all of the skull views gives an impression that the skull belonged to an individual in an age range between 20 and 40 years old, with an average of 30 years old ( - Table $4 \& 5$ ). The MM/OM ratio for the reference skull came out to be 0.81 ( - Fig. 3) which puts the skull in the age range between 20 and 50 years old (-Table 3) 

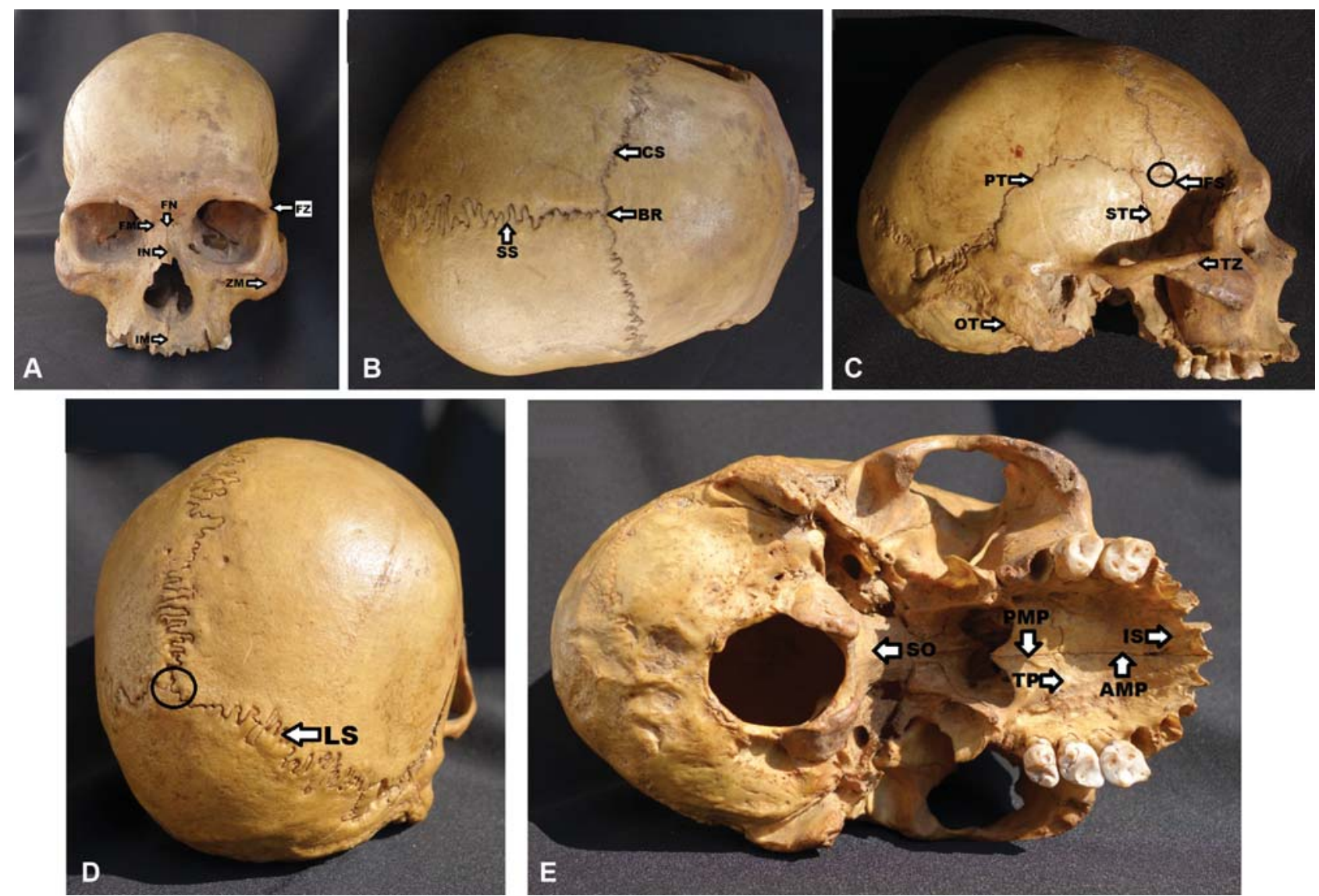

Fig. 2 Composite photograph showing the facial and cranial sutures in different views of the skull under study. A. Anterior View [FM, frontomaxillary suture; FN, frontonasal suture; IM, intermaxillary suture; IN, internasal Suture; FZ, frontozygomatic suture; ZM, zygomaticomaxillary suture;]; B. Superior View [BR, bregma; CS, coronal suture; SS, sagittal suture]; C. Lateral View [Circle marked area,Terion; FS, frontosphenoidal suture; OT, occipitotemporal suture; PT, parietotemporal suture; ST, sphenotemporal Suture; TZ, temporozygomatic suture] ; D. Posterior View [Circle marked area, lambda; LS, lambdoid Suture]; E. Lateral View [AMP, anteromedian parietal suture; PMP, posteromedian parietal suture; SO, spheno-occipital suture; TP, transverse parietal suture; IS, incisive Suture].

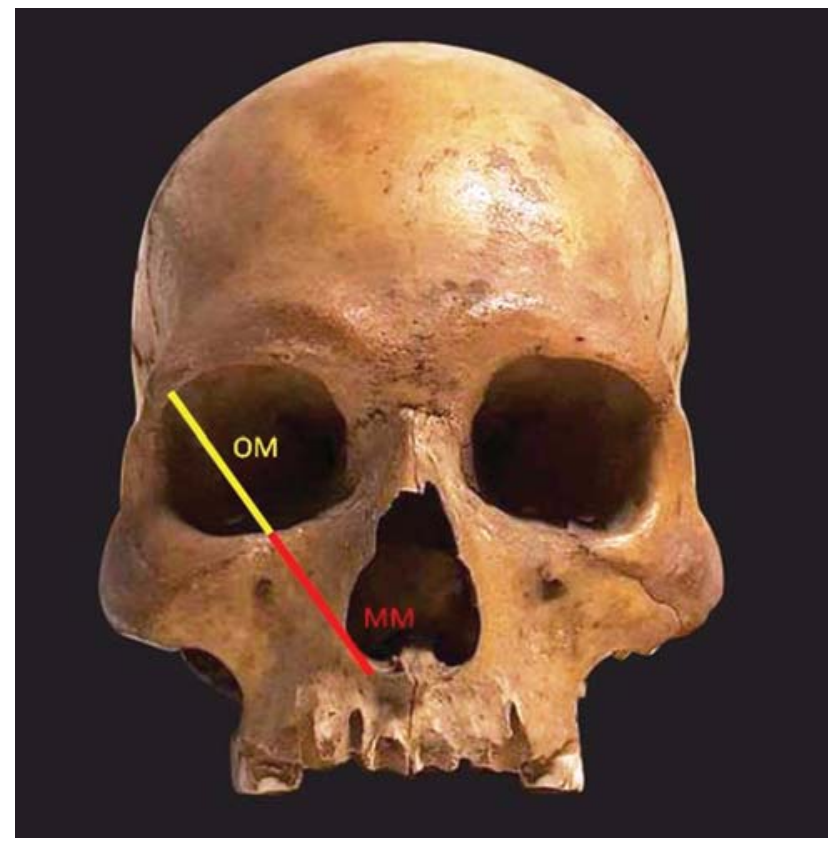

Fig. 3 Anterior view of the skull under study showing the orientation of the orbitomedial (OM) and maxillomedial (MM) facial anthropometric lines.
In observation for the presence of teeth, two molars in the right upper jaw and three molars were found in the left upper jaw (-Fig. 3). Based on the study of the literature, the estimated age for the appearance of the molar teeth, ossification of the spheno-occipital synchondrosis and jugular growth plate came out to be between 17 and 21 years old, 18 and 25 years old, and 22 and 36 years old, respectively.

No significant age-related changes were visible in any facial bone in all of the analyzed views. Age changes in the mandible could not be studied because it was not available with the skull. No dental caries or any age-related changes were found in the molar teeth. The approximate height of the individual to whom the skull belonged was 5 feet 10.8 inches (standard error $[S E]=2.57$ ).

\section{Discussion}

There is little information available on the personal details as well as on the biological relations of Alum Bheg, and the issue of considerable time lapse have made the confirmation of his identification extremely difficult. The unavailability of any known biological relatives for the advanced biological methods like DNA finger printing, and confirmed precision of the radio 
Establishing the Identity from the Skeletal Remains Kumar et al. 325

Table 2 Determination of the Mean Age of the Skull from Established Scoring Systems

\begin{tabular}{|c|c|c|c|c|c|c|}
\hline \multicolumn{2}{|c|}{$\begin{array}{l}\text { Buikstra and Ubelaker }{ }^{3} \text { scoring } \\
\text { system }\end{array}$} & \multicolumn{2}{|c|}{$\begin{array}{l}\text { Cranial and facial sutures/points studied } \\
\text { for chronological age estimation accord- } \\
\text { ing to the Meindl et al system }\end{array}$} & \multicolumn{3}{|c|}{$\begin{array}{l}\text { Anthropometric indexing of age } \\
\text { changes in human skull }\end{array}$} \\
\hline $\begin{array}{l}\text { Score } \\
\text { Points }\end{array}$ & Degree of closure & Serial No. & $\begin{array}{l}\text { Name of suture/points } \\
\text { (Vault group }=1-7 \\
\text { Lateral Anterior group }=6-10 \text { ) }\end{array}$ & $\begin{array}{l}\text { Composite } \\
\text { Score }\end{array}$ & $\begin{array}{l}\text { Mean Age } \\
\text { (years old) }\end{array}$ & $\begin{array}{l}\text { Standard } \\
\text { Deviation }\end{array}$ \\
\hline \multirow[t]{2}{*}{0} & \multirow{2}{*}{$\begin{array}{l}\text { The suture is open, that is, } \\
\text { no evidence of ectocranial } \\
\text { closure }\end{array}$} & 1 & Midlambdoid & \multicolumn{3}{|c|}{ Vault group (1-7) } \\
\hline & & 2 & Lambda & 0 & - & - \\
\hline \multirow[t]{2}{*}{1} & \multirow{2}{*}{$\begin{array}{l}\text { There is a minimal closure } \\
\text { of the suture }\end{array}$} & 3 & Obelion & $1-2$ & 30.5 & 9.6 \\
\hline & & 4 & Anterior Sagittal & $3-6$ & 34.7 & 7.8 \\
\hline \multirow[t]{2}{*}{2} & \multirow{2}{*}{$\begin{array}{l}\text { Sutures with evidence of } \\
\text { significant closure }\end{array}$} & 5 & Bregma & $7-11$ & 39.4 & 9.1 \\
\hline & & 6 & Midcoronal & $12-15$ & 45.2 & 12.6 \\
\hline \multirow[t]{10}{*}{3} & \multirow{10}{*}{$\begin{array}{l}\text { Completely obliterated } \\
\text { suture (complete fusion) }\end{array}$} & 7 & Pterion & $16-18$ & 48.8 & 10.5 \\
\hline & & 8 & Sphenofrontal & $19-20$ & 51.5 & 12.6 \\
\hline & & 9 & Inferior sphenotemporal & \multicolumn{3}{|c|}{ Lateral Anterior group $(6-10)$} \\
\hline & & \multirow[t]{7}{*}{10} & \multirow[t]{7}{*}{ Superior sphenotemporal } & 0 & 32 & 8.3 \\
\hline & & & & 2 & 36.2 & 6.2 \\
\hline & & & & $3-5$ & 41.1 & 10 \\
\hline & & & & 6 & 43.4 & 10.7 \\
\hline & & & & $7-8$ & 45.5 & 8.9 \\
\hline & & & & $9-10$ & 51.9 & 12.5 \\
\hline & & & & $11-14$ & 56.2 & 8.5 \\
\hline
\end{tabular}

Table 3 Anthropometric Measurements Based on Age-Related Changes in the Human Skull

\begin{tabular}{|l|l|l|l|l|l|l|}
\hline \multicolumn{2}{|l|}{$\begin{array}{l}\text { Anthropometric indexing of age } \\
\text { changes in human skull }\end{array}$} & \multicolumn{2}{l|}{$\begin{array}{l}\text { Age-related changes in skull } \\
\text { components }\end{array}$} & \multicolumn{2}{l|}{$\begin{array}{l}\text { Age of appearance of permanent } \\
\text { molar teeth }\end{array}$} \\
\hline $\begin{array}{l}\text { Age } \\
\text { Range }\end{array}$ & $\begin{array}{l}\text { MM/OM ratio } \\
\text { reference } \\
\text { (Male) }\end{array}$ & $\begin{array}{l}\text { MM/OM ratio } \\
\text { reference } \\
\text { (Female) }\end{array}$ & $\begin{array}{l}\text { Skull } \\
\text { component }\end{array}$ & Age-related changes & $\begin{array}{l}\text { Permanent } \\
\text { upper molar } \\
\text { teeth }\end{array}$ & $\begin{array}{l}\text { Age of appearance } \\
\text { (years old) }\end{array}$ \\
\hline$<20$ & 0.75 & 0.78 & Orbit & $\begin{array}{l}\text { Floor of the orbit expands } \\
\text { inferiorly and laterally, } \\
\text { losing the round shape }\end{array}$ & $1^{\text {st }}$ molar & $6-7$ \\
\hline $20-50$ & 0.77 & 0.77 & Maxilla & $\begin{array}{l}\text { An anterior and inferior } \\
\text { bone resorption leading } \\
\text { to retrusion } \\
\text { of the face }\end{array}$ & $2^{\text {nd }}$ molar & $12-13$ \\
\hline$>50$ & 0.66 & 0.71 & Zygoma & Anterior resorption & $3^{\text {rd }}$ molar & $17-21$ \\
\cline { 3 - 5 } & & Mandible & $\begin{array}{l}\text { Loses vertical projection } \\
\text { and fragile }\end{array}$ & & \\
\cline { 3 - 5 } & & & Teeth & Dental caries, attrition & & \\
\hline
\end{tabular}

Abbreviations: MM, maxillomedial; OM, orbitomedial.

carbon $\left({ }^{14} \mathrm{C}\right)$ dating only for the skeletal remains of a recent origin present a limit on use of these advanced biological methods for identification in the present case. ${ }^{6}$ In this situation, studying the age-related morphological changes in the skeletal remains and their correlation with the available documented details may be an acceptable method for establishing the identity of the individual. ${ }^{7,8}$ Age estimation based on the analysis of the age-related morphological changes in facial bones and the closure of skull sutures have long been established methods., ${ }^{3,9}$ The literature gives a clear indication for approximate age ranges for these morphological changes in the human skull. However, chances of error in this estimation are said to be significant, analysis based on the data from multiple sutures and measurement ratio of the facial anthropometric lines may give a closer estimation of the biological age when corroborated with the other evidence, as 


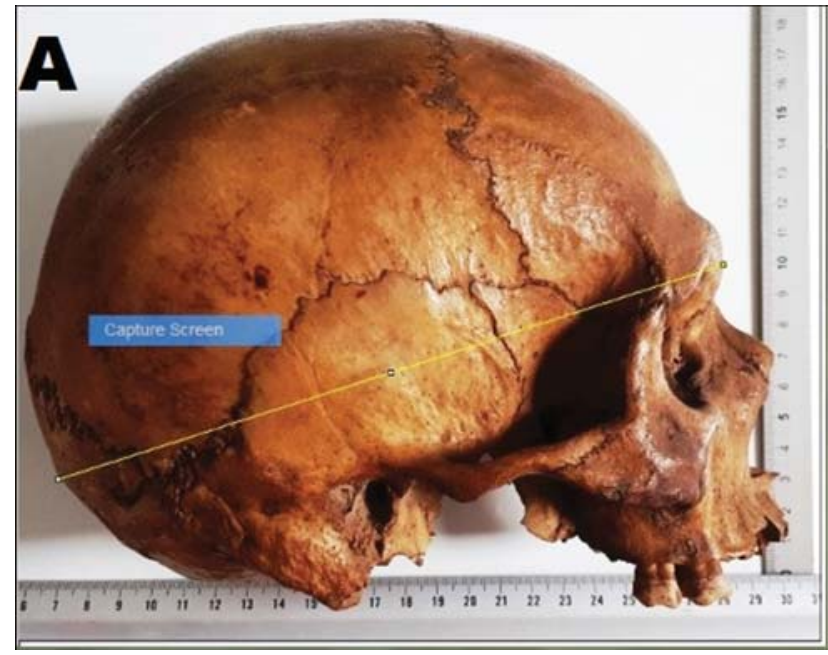

Fig. 4 Estimation of the height of the person from the length of the skull through digital image analyzer (Image J software, National Institutes of Health, Bethesda, MD, USA).

in any other skeletal remains. Estimation of the approximate stature of the individual from the skull dimensions and its match with the value stated in the historical note found with the skull strengthen further the conclusion of the present study.

In the present study, analysis of the gender of the skull based on the established criteria suggested it belonged to a male individual. The $3^{\text {rd }}$ permanent molar tooth present in the upper jaw of the skull gave a confirmation that the individual was not younger than between 17 and 20 years old. The ratio of the facial anthropometric lines $(\mathrm{MM} / \mathrm{OM}=0.81)$ gives an age range of between 20 and 50 years old.

A review of the existing literature suggests the extreme variation in the age of suture closures in reference to the geographical region and ethnicity of the individual. In general, the fusion of cranial sutures is said to start at between 25 and 30 years old, and is completed by between 40 and 60 years old, or even later. The sutures between facial bones may start fusing only in the middle adult age (between 40 and 60 years old) and may not fuse completely until last. ${ }^{9,10}$ In the present study, visible signs of the initiation of the fusion but incomplete closure of the coronal, sphenotemporal, and parietotemporal sutures give indication that the skull belonged to an individual with the actual age most likely being somewhere at the middle of the age range.

Table 4 Age estimation based on the closure pattern of cranial and facial sutures

\begin{tabular}{|c|c|c|c|c|}
\hline Name of suture (cranial) & $\begin{array}{l}\text { Buikstra and Ubelaker } \\
\text { scoring system }\end{array}$ & $\begin{array}{l}\text { Start of fusion } \\
\text { (years old) }\end{array}$ & $\begin{array}{l}\text { Complete closure } \\
\text { (years old) }\end{array}$ & $\begin{array}{l}\text { Estimated age } \\
\text { (years old) }\end{array}$ \\
\hline Coronal & $\begin{array}{l}0 \text { to } 2 \text { from right end } \\
\text { to left end }\end{array}$ & $25-30$ & $40-60$ & $30-40$ \\
\hline Saggital & $\begin{array}{l}0 \text { to } 1 \text { from posterior } \\
\text { to anterior end }\end{array}$ & $25-30$ & $40-60$ & $25-30$ \\
\hline Lambdoid & $0-1$ & $25-30$ & $40-60$ & $25-30$ \\
\hline Parietotemporal & $\begin{array}{l}\text { Right: } 1 \\
\text { Left: } 0-2\end{array}$ & $25-30$ & $40-60$ & $30-40$ \\
\hline Sphenotemporal & $\begin{array}{l}\text { Right: } 0-1 \\
\text { Left: } 0-1\end{array}$ & $25-30$ & $40-60$ & $25-30$ \\
\hline Frontosphenoidal & $\begin{array}{l}\text { Right: } 0-1 \\
\text { Left: } 0-1\end{array}$ & $25-30$ & $40-60$ & $25-30$ \\
\hline Spheno-occipital & 3 & $\ldots$. & $20-25$ & $>20-25$ \\
\hline $\begin{array}{l}\text { Occipitotemporal } \\
\text { (jugular growth plate) }\end{array}$ & 3 (bilaterally) & $\ldots$ & $25-30$ & $>25-30$ \\
\hline \multicolumn{5}{|l|}{ Name of suture (facial) } \\
\hline Fronto-zygomatic & 0 & $40-45$ & May not fuse completely & $<40-45$ \\
\hline Fronto-maxillary & 0 & $40-45$ & May not fuse completely & $<40-45$ \\
\hline Fronto-nasal & 0 & $40-45$ & May not fuse completely & $<40-45$ \\
\hline Inter-nasal & 0 & $40-45$ & May not fuse completely & $<40-45$ \\
\hline Inter-maxillary & & $30-35$ & May not fuse completely & $<30-35$ \\
\hline Zygomatico-maxillary & 0 & $40-45$ & May not fuse completely & $<40-45$ \\
\hline Temporo-zygomatic & 0 & $40-45$ & May not fuse completely & $<40-45$ \\
\hline Anterior median palatine & 0 & $40-45$ & May not fuse completely & $<40-45$ \\
\hline Posterior median palatine & 0 & $40-45$ & May not fuse completely & $<40-45$ \\
\hline Transverse palatine & 0 & $40-45$ & May not fuse completely & $<40-45$ \\
\hline Incisive & 0 & $40-45$ & May not fuse completely & $<40-45$ \\
\hline
\end{tabular}


Table 5 Age estimation based on the closure pattern of the group of cranial and facial sutures

\begin{tabular}{|c|c|c|c|}
\hline $\begin{array}{l}\text { Serial } \\
\text { Number }\end{array}$ & Name of suture & $\begin{array}{l}\text { Buikstra and Ubelaker } \\
\text { scoring system }\end{array}$ & Composite scores versus chronological age ${ }^{4}$ \\
\hline 1. & Midlambdoid & 1 & \multirow{9}{*}{$\begin{array}{l}\text { Vault group ( } 1-7 \text { sutures/points) } \\
\text { Total score }=2 \\
\text { Estimated Age }=30.5 \pm 9.6 \text { years old } \\
\text { Lateral Anterior group }(6-10 \text { sutures/points) } \\
\text { Total score }=4 \\
\text { Estimated Age }=41.1 \pm 10 \text { years old }\end{array}$} \\
\hline 2. & Lambda & 0 & \\
\hline 3. & Obelion & 0 & \\
\hline 4. & Anterior sagittal & 0 & \\
\hline 5. & Bregma & 0 & \\
\hline 6. & Midcoronal & 1 & \\
\hline 7. & Pterion & 0 & \\
\hline 8. & Sphenofrontal & 0 & \\
\hline 9. & Inferior sphenotemporal & 2 & \\
\hline 10. & Superior sphenotemporal & 1 & \\
\hline
\end{tabular}

No indication of the fusion in any facial sutures (except of the minimal evidence of the closure observed in the zygomaticomaxillary sutures bilaterally) further keeps the estimated age in the range between 30 and 40 years old (-Table 4). The complete nonclosure of midpalatine sutures gives an indication that the skull may belong to a person $<35$ years old. ${ }^{11,12}$ In contrast, the complete ossification of the spheno-occipital synchondrosis (between 18 and 25 years old), and of the jugular growth plate bilaterally (between 22 and 36 years old) (-Table 4) also indicate that the skull belonged to a person of the postpubertal age. ${ }^{13,14}$ No signs of caries or any age-related attrition on the teeth and in the facial bones is also a hint that the skull belonged to an individual in the early adult age (between 20 and 40 years old). The assessment of the approximate stature of the individual based on the length of the skull was observed as being between 5 feet 8.2 inches and 6 feet 1.3 inches (against 5 feet 7.5 inches in the historical note). The observed difference of the calculated stature may be attributed to the possible discrepancies between the geographical region of origin of Alum Bheg and values used as references as available in the literature. ${ }^{15}$ The observed values for the age and height are in approximation with that mentioned in the historical note, and slight differences may be attributed either to the gross reporting of the original values or limitations of the anthropometric analysis for these estimations.

In conclusion, analysis of our data suggests that the skull belonged to an individual of the male gender, with an age range between 20 and 40 years old, with an average of 30 years old, and with a height between 5 feet 8.2 inches and 6 feet 1.3 inches. Considerable approximation of the data derived for the age, gender and stature of the individual from the present study with that mentioned in the historical note, which also mentioned the name and few other details, provides veracity of the claim that the skull may belong to Alum Bheg.

\section{Conclusion}

The reference data representative of the Indian male population for the closure of skull sutures was lacking in this study, owing to the extreme paucity of indexed studies in this regard. For the determination of stature, the reference data used in the present study represented only the central Indian geographical region (facing the extreme paucity of the population-specific data), which could be a mismatch to the martyr's place of origin (although little has been documented about that). A matched reference data for the age and stature could have provided a more realistic estimate. Also, including more skull dimension parameters, such as width and perimeter of the skull, could further enrich the assessment. DNA finger printing of tissue procured from the skeletal remains can be matched in the future with close biological relatives of the martyr for eventual validation of the identity of the claimed skeletal remains used in the present study. However, the task would be an extremely arduous one due to the paucity of information regarding the family and place of origin of the martyr. Moreover, one cannot overlook the possibility of population migration within the Indian subcontinent since the event of the Sepoy Mutiny.

Ethical Clearance

Obtained from Institutional Ethics Committee.

Funding

None to report.

Conflicts of Interests

None to declare.

Acknowledgments

The authors express heartfelt gratitude to Dr. Kim A. Wagner, Senior Lecturer in British Imperial History at the Queen Mary University of London, for providing us the Photographs and text details of the Skull of Alum Bheg.

The present research was presented in oral presentation category by the corresponding author in the $66^{\text {th }}$ National Conference of the Anatomical Society of India held at the All India Institute of Medical Sciences, Rishikesh, Uttarakhand, India. 


\section{References}

1 Wagner KA. The skull of Alum Bheg: the life and death of a rebel of 1857. New Delhi: Penguin; 2017:287

2 Krogman WM, İşcan MY. The human skeleton in forensic medicine. Springfield, IL: C.C. Thomas; 1986:551

3 Toledo Avelar LE, Cardoso MA, Santos Bordoni L, de Miranda Avelar L, de Miranda Avelar JV. Aging and Sexual Differences of the Human Skull. Plast Reconstr Surg Glob Open 2017;5(04):e1297

4 Meindl RS, Lovejoy CO. Ectocranial suture closure: a revised method for the determination of skeletal age at death based on the lateralanterior sutures. Am J Phys Anthropol 1985;68(01):57-66

5 Kamal R, Yadav PK. Estimation of stature from different anthropometric measurements in Kori population of North India. Egypt J Forensic Sci 2016;6:468-477

6 Hodgins GWL. Measuring atomic bomb-derived 14C levels in human remains to determine Year of Birth and/or Year of Death Measuring atomic bomb-derived $14 \mathrm{C}$ levels in human remains to determine Year of Birth and/or Year of Death Award Number 2009: 2005-IJ-CX-K013.

7 Lynnerup N, Villa C. Age estimation of skeletal remains: principal methods. Res Reports Forensic Med Sci 2014;4:3
8 Edgar $\mathrm{HJH}$. Estimation of ancestry using dental morphological characteristics. J Forensic Sci 2013;58(Suppl 1):S3-S8

9 Key CA, Aiello LC, Molleson T. Cranial suture closure and its implications for age estimation. Int J Osteoarchaeol 1994; 4:193-207

10 Standring S. Gray's anatomy: the anatomical basis of clinical practice. London, UK: Elsevier; 2016:26-427

11 Vodanović M, Dumančić J, Galić I, et al. Age estimation in archaeological skeletal remains: evaluation of four non-destructive age calculation methods.J Forensic Odontostomatol 2011;29(02):14-21

12 Apostolidou C. Application of the Maxillary Suture Obliteration Method For Estimating Age at Death in Greek Population. Open Forensic Sci J 2011;4:15-19

13 Powell TV, Brodie AG. Closure of the spheno-occipital synchondrosis. Anat Rec 1963;147:15-23

14 Maat GJR, Mastwijk RW. Fusion status of the jugular growth plate: An aid for age at death determination. Int J Osteoarchaeol 1995; 63:163-167

15 Watkins JK, Blatt SH, Bradbury CA, et al. Determining the population affinity of an unprovenienced human skull for repatriation. Journal of Archaeological Science: Reports 2017;12:384-394 